\title{
The influence of the geometric form of flexible diamond discs on the properties of treated surfaces
}

\author{
Paweł Rajczyk ${ }^{1}$
}

\begin{abstract}
:
The shaping of structural elements of flexible discs formed from synthetic diamond powders on synthetic binders is one of the current problems facing researchers when creating new, highly effective machining tools for the processing of mineral materials. Over many years, natural stone and particularly hard types of rock have been used for and still remain a noble, durable and highly appreciated building material for facings. Meeting the normative requirements for shaping functional properties in automated technology systems for processing such materials requires the development of methods for modeling new construction and material solutions for machining tools, especially with the use of diamond abrasives, which are increasingly used in construction technologies. One requirement is to study the influence of the geometrical form of the abrasive segments of flexible machining discs in order to increase the efficiency of the process of finishing granite surface grinding.
\end{abstract}

\section{KEYWORDS:}

abrasive wheels; mineral surface treatment; synthetic diamond powder; synthetic binders; surface roughness

\section{Introduction}

The undertaken work solves the current research problems in the field of granite slab surface treatment technology. The previously used grinding wheels and their structures for finishing grinding of granite surfaces in terms of the effectiveness of abrasive impact have specific geometric characteristics related to the abrasive diamond segments, which are used in common practice. The new solution for the geometric friction surface of the disc structure is the subject of preliminary tests and comparable assessments into the effectiveness of their abrasive impact. The aim of the work is also to increase the efficiency and quality expressed by a uniform distribution of post-treatment roughness in the process of abrasive impact.

Theoretical studies into the influence of kinematic parameters depending on the geometric form influencing the treated surface were analyzed $[1,2]$. The determined direction allowed the conditions to be defined for a new approach to shaping the geometry and materials of abrasive segments produced by the method of forming segments on synthetic binders using pressing and thermal treatment. The use of new material solutions when modifying synthetic binders allows the modification of the hardness at a given abrasive concentration of the discs. The new type of disc structure does not require the use of high temperature annealing, which is used in tools manufactured using powder metallurgy. New construction and material solutions in the production of abrasive segments formed with the use of synthetic binders for the processing of granite provides cheaper and quicker shaping of any geometric structure for the friction segments of flexible discs. The effect of their impact is expressed by the parameter of their

1 Czestochowa University of Technology, Faculty of Civil Engineering, ul. Akademicka 3, 42-218 Częstochowa, e-mail: rajczyk.pawel@wip.pcz.pl, orcid id: 0000-0001-5363-7337 
measured abrasive efficiency, assessed by the roughness of the machined surface on the measured active width of the grinding wheel. The hardness of the abrasive segments is also a factor influencing the abrasive efficiency of the segments of the grinding wheel, which was taken into account in the process of verification tests in order to select the modifiers of the binders used in the matrix of synthetic polymer binders that regulate the hardness of the modeled segment. These parameters result from the relationship between the hardness of the processed material, which is granite, and the hardness of the abrasive segments. Measurements of the hardness of the abrasive segments were determined according to Shore "D" methods.

\section{The desirability of granite slabs}

In construction, natural stone, mainly granite, is used as a cladding material for the execution of: facades, plinths, floors, stairs, etc. The surface treatment of this type of product becomes particularly important, as it gives the opportunity to use the properties of this material, which is resistant to abrasion and wear. An important property of natural stone is also the fact that after polishing, it meets the aesthetic and utility requirements of the construction, as well as those related to the maintenance of cleanliness. The faced surfaces of granite stone slabs, formed after cutting with sawmills, circular saws, diamond ropes and water jets require further technological processes, such as grinding or polishing, in order to smooth the granite surface or to provide a given degree of high-quality polishing. Surfaces treated in this way have the highest resistance to the effects of weather conditions, weathering and resistance to aggressive rains or they meet the standard requirements for shaping the friction coefficient on the treated surface. In the case of using granite slabs for pavements and other pedestrian routes, it is required to ensure the standard safety in the operation of the surface. It is advisable to provide such a surface with a standard surface roughness that guarantees the standard coefficient of friction [3]. Slip resistance measurements are made in two ways: static and dynamic. The basic device used to measure the static friction coefficient is the British friction tester, the so-called English pendulum. The dynamic test is performed by taking measurements with a tire while moving at a constant speed. The slip test method is defined in the PN-EN 13036-4 standard. It is worth noting that the measurement depends on the micro texture of the tested surface. The measurement of skid resistance from stone elements is included in Annex D to PN-EN 1314: 2013-05 entitled "Natural stone slabs for exterior surfaces - Requirements and test methods".

The surface roughness is related to the shaping of operational parameters [4-6], in various countries it is determined by internal standards and normative regulations where the so-called group of parameters shaping the features of safe operation must meet the condition of ensuring an appropriate coefficient of friction depending on the type of function of the room when selecting materials used for the abrasive layer of the usable surface. According to DIN 51131, anti-slip properties for rooms such as: SPAs, swimming pools, and pedestrian crossings must meet standards related to the dynamic friction coefficient, which is determined from the relationship: $\mu \mathrm{k}=\mathrm{T}_{-} \mathrm{k} / \mathrm{N}$, where: $\mathrm{Tk}$ - kinetic force value $[\mathrm{N}]$ and $\mathrm{N}-$ pressure force value [ $\left.\mathrm{N}\right]$. The dynamic friction coefficient should meet the requirements as in Figure 1.

The dependencies cited in Table 1, show the achievable surface roughness parameter ( $\mathrm{Ra})$ defined as the arithmetic mean deviation of the peaks and pits from the mean line, determined according to the GOST 2789-73 standard, depending on the characteristics of the diamond tool, i.e. depending on the granularity of the synthetic powder used and the adopted hardness of the segment binder, where for selected groups of diamond powder grains, the surface roughness was presented for granite surfaces treated with grinding wheels depending on the grain size of the diamond powder used in the binder and the type of binder in the diamond segment matrix [4].

The friction coefficient formed on the surface of the processed material depends on the range of the surface roughness parameter, which is shaped by the tool with the given technical parameters of the disc, i.e. the type of abrasive used, its grain size, and the type and hardness of the segment binder. 


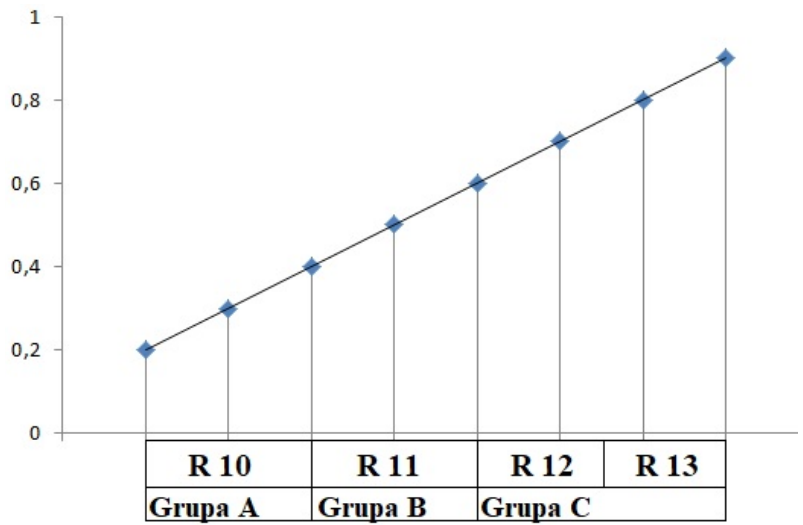

Fig. 1. Requirements for the surface of granite slabs acc. DIN 51131 with regard to ensuring the coefficient of friction, for three groups differentiated by the function of the floor made of stone slabs, where: group A - lounges where the floor is occasionally wet, group B - places called wet, e.g. toilets, group C - places where the floor is often wet [4]

Table 1

Surface roughness depending on the grain size range of the diamond segment of the grinding wheel for metallic and synthetic bonds [4]

\begin{tabular}{|l|l|l|}
\hline \multirow{2}{*}{$\begin{array}{l}\text { Roughness parameter } \mathrm{R}_{\mathrm{a}} \\
{[\mu \mathrm{m}]}\end{array}$} & Diamond segment bond \\
\cline { 2 - 3 } & Metallic & Organo-synthetic \\
\hline $3.2 \div 2.5$ & $315 / 250 \div 200 / 160$ & - \\
\hline $1.25 \div 0.63$ & $200 / 160 \div 125 / 100$ & - \\
\hline $0.63 \div 0.32$ & $125 / 100 \div 80 / 63$ & - \\
\hline $0.32 \div 0.16$ & $63 / 50 \div 50 / 40$ & $80 / 63 \div 63 / 50$ \\
\hline $0.16 \div 0.08$ & - & $63 / 50 \div 50 / 40$ \\
\hline $0.08 \div 0.04$ & - & $40 / 28 \div 28 / 20$ \\
\hline $0.04 \div 0.02$ & - & $20 / 14 \div 10 / 7$ \\
\hline
\end{tabular}

\section{Technical requirements for the assessment of the granite slabs' surface}

In Poland, the basic documents regulating the principles of testing, evaluation and marking of natural stone products admitted for use are the regulations contained in the Act of 07/07/1994 Fri "Construction Law" and the three implementing regulations of the Minister of Internal Affairs and Administration related to this act:

- Regulation of August 5, 1998 on approvals and technical criteria as well as individual use of construction products (Journal of Laws of 1998, No. 107, item 679);

- Regulation of July 31, 1998 on conformity assessment systems, the template of the declaration of conformity and the method of marking construction products admitted to trading and common use in construction (Journal of Laws of 1998, No. 113, item 728);

- Regulation of July 24, 1998 on the list of construction products having no significant impact on the fulfillment of basic requirements and products manufactured and used in accordance with recognized principles of construction art (Journal of Laws of 1998, No. 99, item 637).

In the research, to evaluate the surface roughness parameter, a measuring stand was used in which a device for measuring the surface roughness operated in accordance with the diagram shown in Figure 2. 


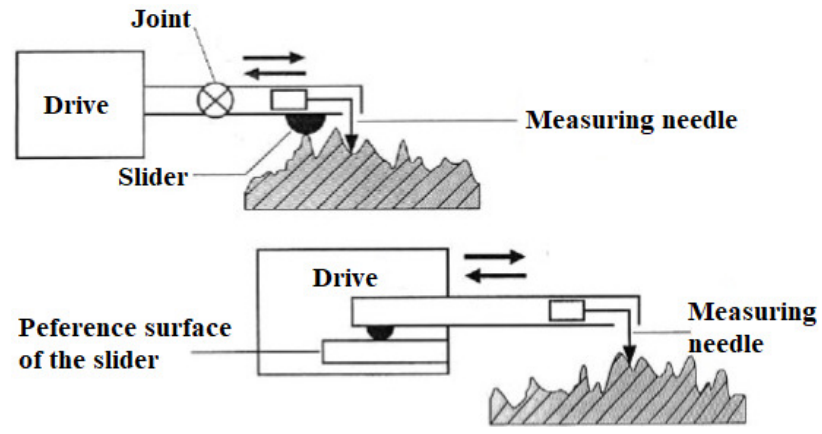

Fig. 2. Operation of devices intended for surface roughness testing [7]

The main principle of surface roughness testing is that a sensor connected to a computer measures very fine surface irregularities.

The basic parameter when assessing the post-treatment effect of granite surfaces is the measurement of the post-treatment surface roughness (Ra parameter), measured with the device shown in the diagram. The measurement was performed with a very high level of accuracy of the deviation of the measuring tip position on the section predetermined by Polish standards.

The length of the section (measured in millimeters) for the length of the measuring line from the diameter or radius of the disc may be, for the assessment of the surface of the processed granite slab: 8; 2.5; $0.8(\mathrm{~mm})$ [4]. The parameter (Ra) is calculated from the formula (1):

$$
\mathrm{R}_{\mathrm{a}}=\frac{1}{I} \cdot \int_{0}^{l}|y(x)| d x \approx \frac{1}{n} \cdot \sum_{i=1}^{n}\left|y_{i}\right|
$$

where: $\mathrm{l}$ - length of the section on which the measurement was carried out; $\mathrm{y}(\mathrm{x})$ - a function that describes the surface of the object; $d x$ - width of the elementary surface area; $y_{i}-$ deviation of the i-th measurement point from the mean line [8].

The measured deviation of $y_{i}$ from the $\mathrm{x}$ axis is in the order of parts of a millimeter, therefore the parameter ( $\mathrm{Ra}$ ) is defined in $\mu \mathrm{m}$. From this, the final form of formula (1) shows the simplest numerical integration algorithm by the rectangle method. There is a more accurate version of the above formula, which is based on the numerical trapezoidal integration method, which is used by Mitutoyo profilometers.

\section{Synthetic binders for making grinding wheels}

Resin binders are characterized by high mechanical strength and achieve a hardness of up to about $90 \mathrm{ShD}$. When assessing the suitability as a bond for diamond segments, they have a shortcoming, i.e. low resistance to high temperatures. Currently, the area of application of composite materials for the production of diamond-resin segments and tools is used for processing hard and brittle materials that form the so-called short chips and in an operating environment where there is low temperature in the contact zone of the grain with the material being processed, i.e. working at low-speed. Resin-bonded diamond grinding wheels can work both with coolant and in the so-called dry regime, which is a less effective method.

Compared to metal-bonded tool segments, resin-bonded grinding wheels have lower strength, but allow the use of a smaller grit size with an extended diamond grain surface in the grinding wheel for a given operation. They make it possible to reduce the diamond concentration to a given class of machining operations, which results from the properties of a synthetic binder characterized by a greater ability to keep the grain in the binder. The range of abrasive concentration in finishing grinding wheels is $15 \div 50 \%$. The preference for the use of a low 
concentration of abrasive in tools for finishing operations allows for a homogeneous surface roughness while ensuring high machining efficiency. The production technology of diamond segments consists in preparing a mixture of diamond powder, with a given grain size depending on the intended use of the technological operation, modifiers, filler and resin. The material prepared in this way is subjected to the process of mixing and initial pressing, and then hot pressing with annealing the wheels at a temperature appropriate for the hardening of a given type of resin. The hardness of the diamond segment is regulated by the type of filler, the material of modifiers that allow the hardness parameter to be specified in a narrow range, which determines the performance properties of a given cutting disc. The amount of filler and its type affects the economic and technical effects of the work process of a given machining disc. The grain size and concentration of the synthetic diamond powder should be selected in a way that will not cause a significant scattering of machining scratches during micro-cutting, the assessment of the abrasive efficiency is carried out with one pass of the disc on the treated material. Due to its very good thermal conductivity, the modifier in the form of nanodiamonds causes a significant increase in heat dissipation from the working zone of diamond grains, thus ensuring the ability to keep the working grains embedded in the segment binder. The nanodiamonds also allow the hardness of the diamond segment to be regulated within a narrow range. The introduction of metal powders into the binder also has a positive effect on the homogenization of the composition of the composite to reduce the heat generated in the working zone. Metal powder modifiers have the task of regulating the hardness of the binder. Quartz flour is most often used as a filler [9], manufacturers use other types of fillings depending on the purpose of the abrasive segments, for this purpose the following are used: powdered glass, titanium oxides, silicates and halides, e.g. cryolite. In Poland, the chemical plants in Pustków have gained extensive experience in the production of tools based on phenoplastics [10,11]. Modern binders for the production of diamond segments are compositions based on acrylic, epoxy and polyurethane resins. Their hardening consists of introducing reactive functional groups into the prepolymer particles, thanks to which it is possible to control polyreaction and crosslinking. An example is a resin called Xylok, which contains radicals that are substituted for hydrogen. The effect of such modification is to increase the thermal resistance of the diamond segment produced from such a binder. The recipes for the composition of resin raw materials are a well-kept secret of the manufacturer and they are not widely available.

The manufacturing process for such tools consists of spreading the uncured resin-based composite mixture onto fabrics, wire mesh or plastic films. The production process consists of pressing and hardening it with thermal treatment. In the process of work, such a tool, due to the nature of its use, must have the so-called deformability, therefore the hardened resin must be flexible and resistant to multidirectional effects of compressive and tensile forces. A very important factor influencing the abrasive efficiency and flexibility of the product is the shape of the abrasive segment, i.e. various shapes of the working protrusions of the segment and the resulting discontinuities in the segment embankment. An example of such shields is shown in Figure 3.

a)

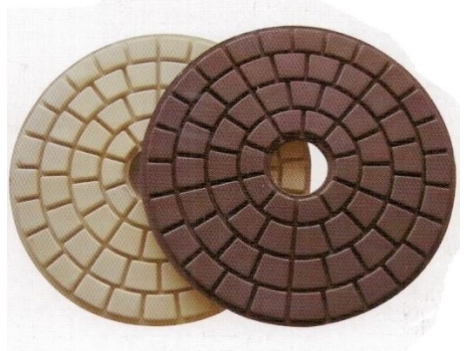

b)

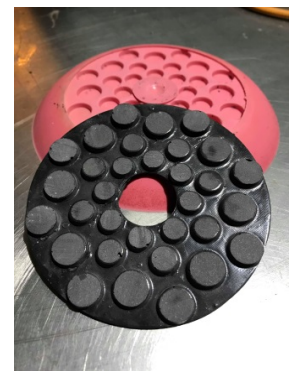

Fig. 3. An example of machining discs for a quick connection of the "Velcro" type made on a synthetic binder $[12,13]$ 


\section{Conclusions}

It is advisable to improve the measurement methods and to present the problem of the need to measure roughness at the execution stage and during pavement operation. Roughness coefficients for road surfaces and usable surfaces should be required in the execution specification. This factor determines the safe operation of utility pavements.

The global development of the production technology of synthetic diamond powders and synthetic resins has contributed to the development of the production technology of machining tools, including abrasive wheels for grinding and polishing of mineral surfaces.

Currently, the grinding and polishing of mineral surfaces is performed with flexible abrasive wheels on synthetic binders. Due to the global development of materials used in the production of machining tools, it is advisable to conduct continuous physical and mechanical research into the composition of the composite intended for the formation of synthetic abrasive segments.

\section{References}

[1] Rajczyk J., Modelling the geometricstructure of concreteworkitemprocessing, Applied Mechanics and Materials, 2013.

[2] Rajczyk J., Podstawy naukowe doboru struktury geometrycznej i kinematyki tarczowych narzędzi roboczych maszyn do obróbki powierzchni betonu, Wydawnictwo Politechniki Częstochowskiej, Częstochowa 2004.

[3] Niemiecka norma DIN 51130.

[4] Rajczyk P., Kurakina E., Knapiński M., The influence of surface topography on the safety of road and utility surfaces, Transportation Research Procedia 2018, 36, 640-648.

[5] Duszyński A., Jasiński W., Identyfikacja i ocena nawierzchni drogowych, Logistyka 2015, 4, 3071-3075.

[6] Evtiukov S., Vasilev Y.V., Darożno-transportnyje proishestvia, Rassledovanie rekonstrukcia, ekspertiza, Izd. DNK, 2008

[7] Katalog firmy Mitutoyo.

[8] www.obliczeniowo.com.pl

[9] Rajczyk P., Knapiński M., Analiza teoretyczno-doświadczalna tarcz przeznaczonych do szlifowania wykończeniowego powierzchni granitowych, materiał przekazany do druku, 2019.

[10] Materiały informacyjno-techniczne The Industrial Diamond Association of America

[11] Materiały informacyjno-techniczne Fabryki Wyrobów Precyzyjnych w Warszawie.

[12] Materiały informacyjno-techniczne firmy 3M.

[13] Patent UP RP nr Pat.236487 (opracowanie autorskie).

\section{Wpływ kształtu geometrycznego elastycznych tarcz diamentowych na właściwości obrabianych powierzchni}

\section{STRESZCZENIE:}

Kształtowanie elementów konstrukcyjnych elastycznych tarcz formowanych z syntetycznych proszków diamentowych na spoiwach syntetycznych stanowi jeden z aktualnych problemów w zakresie badań nad tworzeniem nowych wysoko efektywnych narzędzi obróbczych do obróbki materiałów mineralnych. Kamień naturalny, szczególnie twarde rodzaje skał, od lat były i nadal pozostają szlachetnym trwałym i wysoko docenianym materiałem budowlanym, stosowanym jako materiał okładzinowy. Spełnienie normatywnych wymagań w zakresie kształtowania właściwości użytkowych w zautomatyzowanych systemach technologii obróbki takich materiałów wymaga opracowania sposobów modelowania nowych rozwiązań konstrukcyjno-materiałowych narzędzi obróbczych szczególnie z wykorzystaniem ścierniwa diamentowego, które $\mathrm{w}$ technologiach budowlanych znajdują coraz większe zastosowanie. Jednym z nich jest zbadanie wpływu formy geometrycznej segmentów ściernych elastycznych tarcz obróbczych w celu zwiększenia efektywności procesu szlifowania wykończeniowego powierzchni płyt granitowych.

\section{SŁOWA KLUCZOWE:}

tarcze ścierne; mineralna obróbka powierzchni; syntetyczny proszek diamentowy; spoiwa syntetyczne; chropowatość powierzchni 